\title{
SOME ASPECTS OF SOCIAL SECURITY IN MEDIEVAL ENGLAND
}

\section{Elaine Clark*}

\begin{abstract}
Medieval historians have long maintained that social welfare in the communities of rural England often involved private systems of support for the elderly. Individually arranged pension plans provide a case in point. The best evidence of these pension plans is found in the records of manor courts. To read the records is to learn how pension plans enabled the elderly to adjust their needs to local patterns of production and domestic structure, to law, to expressions of personal autonomy, and the confines of personal dependency. Simply stated, the old accommodated their needs for support by looking to benefactors to manage their lands and tenements. The subsequent arrangement involved a contractual agreement designed both to ensure and to supplement familial support, and also, under certain circumstances, to provide a substitute for it. As a result, not even peasants without children or spouses necessarily experienced dislocation. Contracts assured cooperation. They afforded the partners a way to negotiate mutually beneficial bargains wherein the conditional transfer of property was meant to guarantee security during retirement.
\end{abstract}

Much that has been written about the design of social welfare in premodern England has been focused on laws for the poor, on institutions for the orphaned, and property arrangements for the widowed (Page, 1930; Webb, 1966; Pound, 1971). ${ }^{1}$ Much, too, has been said about the correspondence between support systems and inheritance customs, about primogeniture, partibility, and the impact of both on the livelihood of the young (Goody et al., 1976). Yet little has been said about social security for the aged. Instead it is widely assumed that in the communities of

* Elaine Clark is Assistant Professor of History at the University of Michigan, Dearborn. Her current research involves customary law, labor law, and commerce as depicted in the courts of towns and villages in late medieval England.

'A briefer version of this paper was read at the 1981 meeting of the Social Science History Association in Nashville, Tennessee. I am grateful for sug. gestions and criticisms from the audience. rural England the family provided the source as well as the means of income maintenance for the elderly (Homans, 1941). This hypothesis is of considerable interest on dual grounds. First, it links kin-behavior to the distributive system, that is, to the way land and resources were held, utilized, then transferred from aging parents to children. Second, it sees their relationship in terms of an informal compact between the generations, whereby the labor of the young provided support for the final years of the old. Simply put, the family is judged as the measure of mutual aid. Still, it may be asked if, in addition to the family, local law and custom ever defined aspects of economic security in the society of former times.

To consider the matter, I propose to look at one system of support that was available in the villages and small markettowns of late medieval England. The system afforded the elderly the means to 
surrender the use of their lands and resources to family members or nonkin in exchange for individually arranged pension benefits. In other words, the conveyance of land accorded the old a highly personalized strategy for maintenance. This strategy usually involved customary land held at the will of a manor's lord in return for rent and services. Every transfer of such a holding, no matter what its occasion, had to be reported in the lord's court. He alone had the right to determine the acceptability of tenants. They received land from "the hands of the lord," and he, in turn, demanded a cash payment for permission to enter a holding. Consequently, his interest in the transactions of the aged was hardly gratuitous. He not only derived a portion of his income from rents and fines, but relied on hardworking peasants to plow his demesne, to labor at harvest, to perform, in effect, prescribed customary services. Moreover, the obligations generated by a pension were enforceable in his court. There, men and women informed the bailiff of the pensions they had arranged; there, too, the court's clerk made a notation of the matter. In cases such as these, where the lord's interests were at stake, the court record was detailed and complete.

For this reason, manorial documents can bring into sharp focus the personal needs which men and women, once they became pensioners, uniformly expressed. What must be kept in mind, however, is that court rolls cannot be taken to imply that only written agreements facilitated support for the needy. Nor can we say that pensions necessarily superceded informal understandings between parents and children. Although there is no firm concensus on the issue (Macfarlane, 1979: 141-144), one may surely suppose, as a number of historians do, that familial expectations could have precluded a need for court-recorded support in all instances of parents surrendering land to sons and daughters (Homans, 1941:155; Hilton, 1975:29; Razi, 1981:7-8). What we see in court rolls, then, is the decisions of pensioners rather than the concerns of all aging tenants. The needs of pensioners alone inform the discussion that follows.

The problem is to understand how pension plans enabled the elderly to adjust their needs to local patterns of production and domestic structure, to law, to expressions of personal autonomy, and the confines of personal dependency. What I will argue is that pensions represented a calculated response to problems of change induced by a configuration of factors ranging from the onset of physical infirmity, to the coming of age of children wanting land in order to marry, to a peasant's sudden weariness of years of hard labor. To accommodate their need for support, the old sought benefactors to manage their lands and tenements. The subsequent arrangement involved a contractual agreement designed both to ensure and to supplement familial support and also, under certain circumstances, to provide a substitute for it. As a result not even peasants without children or spouses necessarily experienced dislocation. Contracts assured cooperation. They afforded the partners a way to negotiate mutally beneficial bargains wherein the conditional transfer of property was meant to guarantee security during retirement.

In any discussion of the place of the retired in rural society, we need to remember that accurate statistical records on old age are relatively recent; we cannot say exactly what proportion of medieval households contained elderly tenants. Yet, we have been reminded that an interest in age often informed the commentaries writted by English chroniclers (Hatcher, 1977:58-61). At the time of the Black Death (1349), contemporaries felt that plague struck hardest at the young and the old. Afterwards, particularly in the early 
1360 s, many witnesses had no doubt that "young men" and "children" fell victim to "pestilence" in disproportionately large numbers. Even though chroniclers offer little statistical corroboration, their opinions are suggestive. Recurrent plague and epidemic disease must have radically altered the age-structure of the English population during the latter half of the fourteenth century. ${ }^{2}$ The problem of ageselective mortality, while at issue among demographers, still indicates that a concern for old age need not always be seen as peculiarly modern.

Historians familiar with medieval source-material suggest that Englishmen, at least by the thirteenth century, were well-acquainted with pensions. ${ }^{3}$ Popular literature and sermon exempla confirm the impression albeit indirectly. They were written to warn of the harsh treatment that awaited elderly peasants who gave all that they had to the young in return for food and shelter (Homans, 1941; 154-157; Hilton, 1975:29). In these situations the surrender of land was said to have effected a dramatic change in status: parents became dependents and fared little better than any beggar. On this point, many literary sources are consistent.

Still, court rolis actually contain much of the best evidence we have to trace the social and legal factors that affected the status of some men and women in old age. At the insistence of the manor's lord, clerks made a matter of record the names and responsibilities of guardians appointed to aid villagers thought to be senile or too old and feeble to manage customary tenements on their own. Clerks, too, might

\footnotetext{
${ }^{2}$ See Razi (1980:150-151) for a discussion of the age structure of the adult population in the early 1390 s at Halesowen in Worcestershire. He suggests that tenants in their twenties and thirties comprised 38 percent of the tenant population of the manor in 1393 (compared to 65 percent in 1350).
}

${ }^{3}$ See Appendix for specific references. include in their rolls full copies of wills whenever testators had arranged for special supervision of their estates or maintenance of their widows. Of equal interest is the land litigation initiated in manor courts, for it often reiterates the evidence of custom in order to establish the partibility or impartibility of tenements, the evidence of sworn testimony to establish the chronology of succession, and also the genealogical evidence needed to settle family disputes. In addition, we find that aging freeholders might use courtrecorded recognizances to report the surrender of their holdings, while upon occasion small parcels of freehold were included in the land transferred from one customary tenant to another.

We can know in fair detail about most of these matters by examining court records that are concentrated as to place and continuous over time. East Anglian records are both. The range of information they contain is remarkably diverse. It brings into focus the customary law concerning premortem transfers of land. It outlines the domestic arrangements linking father to son, and grandfather to grandson. It indicates the economic needs of young and old in a rural economy characterized by grain production and animal husbandry, and also, and no less importantly, by trade. Local land markets were continuously active as were the commerical networks that engaged a number of peasants in weekly markets and annual fairs (Campbell, 1980, 1982; Smith, 1979; Clark, 1982). This was a region of considerable prosperity where villages and little market towns provided goods and produce for local consumption as well as for export to London and beyond. Between town and country there existed a reciprocity of economic interests that facilitated trade in wool, dyestuffs, textiles, fish, leather and dairy products. The complementary demands of agriculture and industry accustomed East 
Anglia to the intricacies of commerce, and its inhabitants to the mechanics of hard bargaining. Villagers were familiar with credit and the deliberate calculation of present needs against anticipated income. They adjusted to chronic cash shortages by buying, selling and exchanging their wares against the promise of payment at some future time. They negotiated loans, sold land and mortgaged it, sublet fields, hired out farm implements and livestock at fixed terms. Even the hire of labor was viewed contractually. In consequence, a web of outstanding obligations characterized the exchange of services and goods by men and women who knew to a penny what they had spent or what they must earn. Within this context, contracts for maintenance in old age take on added interest.

The arrangements are amply evidenced by the contracts discussed here (see also Appendix). There are 114 contracts from twenty-one manors in Norfolk; 23 contracts from seven manors in Suffolk; 22 contracts from six manors in Essex. Comparison to an equally important district, mainly in modern Cambridgeshire, may be made by reference to the Ramsey Abbey records edited by E. B. DeWindt (1976) and J. A. Raftis (1964); together they note 35 maintenance arrangements. Supplemental data (6 cases) can be drawn from three manors nearer London, from Harrow in Middlesex and from Cookham and Brightwalton in Berkshire. My primary concern, however, is East Anglia and its 159 cases; threequarters of them fall in post-plague years. ${ }^{4}$

The economic climate of these decades is well known (Postan, 1972, 1973). There was a progressive decline in population and, as a result, a relative improvement in the ratio of land to labor. Wages steadily moved upward but prices, in the mid-

${ }^{4}$ The 159 cases cover the following years: $1258-1299$ (12); 1300-1349 (33); 1350-1399 (42); 1400-1449 (64); 1450-1457 (8). 1370s, began to fall-a fall which, apart from a partial recovery in the early $1400 \mathrm{~s}$, persisted until well into the mid-1500s (Hatcher, 1977:47-54). The net effect of these trends in prices and wages was to strengthen a worker's purchasing power, especially insofar as he received payment in cash rather than kind. A similar pattern may be projected for any pensioner receiving a fixed cash annuity.

The evidence further suggests that the complexity of the economic environment influenced not only the situation of the old, but also the attitudes of the lord and other tenants to the issue of retirement. We therefore find that there were three ways in which pensions, whenever necessary, were arranged.

In the first, support was court ordered and served the interests of the elderly and the demands of the manor's lord. His rights along with their obligations came under the purview of local juries. Any infraction of a tenant's duty they reported in court. Thus at Hindolveston in Norfolk, during 1382 , the jurymen said that in the village there lived a "poor little woman," a widow holding some eighteen acres of arable; she was "feeble of body and simple of mind," unable to care for herself and without the means to render services to the lord (NRO 4818. St. Mark 5 R II). He therefore decided to grant the land to her "nearest heir," ordering him to support the poor woman for life, and to feed and clothe her as befitted a widow. Three other Norfolk cases, also from the later fourteenth century, detail official interference in the affairs of village women worn-out by age and declared mentally incompetent. All were widows; all had kin living nearby except one, whose holding of three acres the lord assigned to two local men on condition that they seed, plow, and harvest the land, using its crops to provide the widow with "all her necessities" (NRO 12475. St. Matthew 19 E III).

In the second place, we also find 
maintenance planned by two parties on behalf of a third, but the arrangements were voluntary rather than officially mandated. They involved deathbed settlements usually, but not always, devised by husbands for their wives. Their maintenance was committed to the income expected from land and became a matter of record because out-of-court surrenders of customary tenements had to be made in the presence of manorial officials. In this way John Whytyng, when he lay dying at Wymondham in 1407 , surrendered a messuage, four acres, three and one-half rods of land, to Simon Wellyng (NRO 18484. St. Faith 9 H IV). Whytyng then established the following conditions for the future support of his widow: She was to have her food and drink, also sixteen bushels of malt annually. For her use, Simon Wellyng must maintain six hens, one goose and one cow; he must cultivate and seed an acre of arable in every season of the year. To her he must give one pair of shoes annually at Easter and three shillings for clothing. Finally, he and the widow must share her late husband's house. She was to have "freedom of entry," a place by the fire, and a bed. These were straightforward provisions for a woman unable to manage on her own. Yet it must not be imagined that all widows were in need of support. Many retained at least partial control of tenements after their husband's premature death. ${ }^{5}$ Hilton (1975:99) has cited a list of tenants compiled at Ombersley in Worcestershire where, during 1419 , one tenant in seven was a widow. Although these women often remarried, they remained quite capable of conducting business for themselves and, when necessary, of bargaining for pensions on their own.

'Manorial customs allowed a widow to hold all or a portion of her husband's tenements for life. For discussion of dower and widow's free-bench, see Hilton (1975:99-100); Homans (1941:177-210); Raftis (1964: 46).
Third are the bargains which pensioners themselves negotiated, which comprise the bulk of support cases on record. These arrangements allowed the greatest range of personal choice at a time when no public agency took full responsibility for the elderly and the intirm. Men and women had to exercise individual initiative, to rely on self-help and mutual aid, even, upon occasion, on the sympathies of a manorial lord. An early case from Norfolk combines all these issues (NRO DA 1. Holy Trinity $15 \mathrm{E} \mathrm{I})$. William de Toneville came into the court at Heacham and spoke of his "old age, his physical disability and poverty." Their coincidence, he said, prevented him from profitably cultivating his land without help from "friends" or his son. Hearing this, the bailiff and steward took counsel with their lord, the prior of Lewes, in whose service the old man's son had been for a very long time. Thereupon it was decided to approve the surrender of the father's house and lands to his son, along with the father's obligations for rent, service, and the maintenance of a daughter. The son, for his part, agreed to feed, clothe, and "honestly support" both of his kin. To confirm the arrangement, which was designated a covenant, he paid the prior a mark (13s 4d).

Individually arranged pensions were meant to be contracts. They rested on a quid pro quo, on the transfer of property in return for maintenance. Whether they concerned spouses or kin, neighbors or strangers, the form of these transactions, their language and intent remained the same (Raftis, 1964:71). Benefits accrued to the pensioner while land, and occasionally moveable chattels, passed to his benefactor. A reciprocity of obligations initiated their relationship and rendered it unmistakably complex. At one level, it involved a mutual bargain; at another, its daily conduct entailed a chain of ongoing duties explicitly encumbent on the new tenant alone. 
Few pensioners, when appearing in court, agreed to anything beyond the surrender of their cottages, farm buildings, and acreage. Those who undertook to do more apparently were motivated by economic need. For smallholders, in particular, a modest parcel of arable might carry little bargaining power if, as it is often supposed, two to three acres were required to support one person at subsistence level (Titow, 1969:79-81; Hilton, 1975:198-199). To secure support the poor sometimes had to make additional concessions. A good example comes from Wymondham in Norfolk where a married couple obtained maintenance by transferring to the new tenants, a man and his wife, not only one acre of arable, a messuage and its appurtenances, but also sheets, carpets, quilts, napkins, clothing, and all household utensils except two pots, two bowls and two wooden chests (NRO 10049. Exaltation of the Holy Cross $17 \mathrm{R}$ II). In similar manner at Hindolveston in Norfolk, a husband and wife surrendered their house and five acres of land to a local couple and agreed to work for them for as long as it was physically possible. In return, the pensioners requested lodging in their former house and the same food and drink allotted to any servant (NRO 4871. Translation of St. Benedict 21 R II).

There seems little doubt that hard individual bargaining accompanied these and other maintenance agreements. Their provisions commonly varied with the needs of the individual parties to the contract. ${ }^{6}$ Those pensioners with more than a few acres of arable at their disposal expressed a variety of demands. Some men who had unpaid debts requested that new tenants discharge the obligations; others simply wanted their clothing washed on a regular basis; still others requested bed-linens and, at least, a tunic, a cape or a cloak.

"For references to the examples given in this paragraph see Appendix.
Many wanted the promise of fuel or a room with a hearth. Villagers anticipating an active retirement might request access to horses for riding or to "hemplond" for cultivating a cash crop; some demanded vats for brewing, ovens for baking, shears for cutting cloth. Pensioners who were evidently quite infirm either wanted friends to visit their sickbed or planned funeral processions and arranged for their burials, also asking that prayers be said for their souls. ${ }^{7}$ But all pensioners, whether enfeebled by age or not, shared one basic concern: they wanted assurance that their needs would be met.

For this reason, the transfer of land remained conditional. Any suspension of support, any failure to discharge the obligations imposed by contract, became subject to penalty. The principal penalty comprised reversion of the land in question to its previous holder. ${ }^{8}$ The resurrender was a matter of custom as well as law, and the legal procedures facilitating its execution depended on the terms the pensioner had included in his contract. On many Norfolk estates the terms were worded in similar ways. Some stipulated that if the new tenant failed, either in whole or in part, to discharge his obligations to the old, and it was so proven by twelve honorable men of the neighborhood, then the previous tenant would

'In 16 contracts pensioners give explicit directives concerning burials, funerals, masses for the dead, and the right of executors or an "attorney" to remove chattels. For one woman's insistence that on the day of her burial a cow accompany her bier, see SRO HA 504/1/9. Translation of St. Thomas martyr $16 \mathrm{R}$ II. For the right of friends to visit the pensioner's sickbed and offer "consolation" see NRO 8861. St. Peter-in-Chains 31 H VI.

${ }^{8}$ For the case of a widow ousting her son and daughter-in-law, and then bestowing her land elsewhere in order to secure the maintenance which they had failed to provide, see Searle (1979:37). For a similar case in Suffolk, see SRO HA 504/1/12. St. Michael $6 \mathrm{H} \mathrm{VI.}$ 
reenter the land and hold it as before. Other clauses allowed the aggrieved pensioner to reenter his tenement at the "grace of the lord" or the "witness of the homage." All the clauses rendered any dereliction of duty to the old a matter of public concern and communal review, of possible censure, even of intervention.

This was also the case when contracts involved additional guarantees to safeguard the pensioner's rights. A son might use the forum of a manor court to ask all present to witness his oath to provide sustenance to parents in need (NRO 19496. Ash Wednesday 53 H III). In addition, he might ask neighbors and kin to stand surety for him, to stake their reputations on his promise of parental support. The practice was fairly frequent and long in use. To have it made a matter of record, the young reported the names of their pledges to the steward of the local court. The subsequent entry resembled a recognizance, at least in its intent. Written recognizances, like personal sureties, guaranteed outstanding obligations. By way of illustration, a son came into court and acknowledged that he owed food, clothing, and shelter to his parents for life (ERO D/DP M19. Holy Trinity 33 E III). He conceded that if he were negligent, the bailiff should distrain his goods and chattels, holding them until the obligations were discharged. If the son indeed defaulted, parents did not have to initiate legal proceedings demanding support. The recognizance was equivalent to a judgment. It gave a court the right to proceed with execution as soon as default occurred. As might be expected, pensioners themselves often paid the fines a court requested to enroll the recognizance.

All these guarantees give the impression that pensioners left little to chance, especially during years when recurrent plague and epidemic disease occasioned high mortality, particularly among the relatively young. Pensioners meant to secure support for life and, in so far as possible, avoided leaving their maintenance to the good intentions of any one individual. When the old planned their retirement, the provisions they negotiated routinely included one of two qualifications. The first subjected tenure to recall. In other words, if the new tenant died, the land reverted to the old; then he renegotiated the pension contract with a partner of his choice. The second qualification, and the more usual one in Norfolk and Essex, made support encumbent on "whomsoever held the tenement," that is, on any tenant who, during the pensioner's lifetime, derived title from the surrender in question. In this instance a villager surrendered land into the hands of the lord to the use of the new tenant, his heirs and assigns. The lord, through his bailiff or steward, granted possession (seisin) to the new tenant on condition that he, his heirs and assigns maintain or arrange for the maintenance of the old. The transaction encumbered land with a personal obligation. It made tenancy contingent on support, which need not cease should the new tenant predecease the old.

The obligation, like a debt, was transferable from one generation to the next, from one assign to another. The chronology of these transfers can disclose a variety of familial relationships. At Ingatestone, in 1415, a jury informed the court that a village smallholder, shortly before he died, surrendered a cottage and one acre of arable to his wife's use on condition that she feed, clothe and support his enfeebled (decrepita) sister for life (ERO D/DP M32. St. Edmund $3 \mathrm{H} \mathrm{V}$ ). His wife agreed and, because she was "poor," asked the court to relax its usual entry fine. The court concurred. The two women lived together for the next six months; then the widow vacated the cottage. She arranged for a local man to have the land, and with it, the obligation of her sister-in-law's support. He shared 
the cottage with the old woman for one year before selling it and the acre of arable to another villager. This man, in turn, sold the land and its cottage in $\mathbf{1 4 1 8}$ for twenty shillings. By then their elderly tenant seemingly was dead. Other transfers, while less complicated than these, leave no doubt that new tenants might live with the old, attend to their needs, cultivate their land, discharge seigneurial dues, only to decide to set up housekeeping on their own. This was the case at Hindolveston, in 1389, when a daughter sold her father's messuage and three acres; and at Chatteris, in 1446, when a son transferred his mother's cot-land (NRO 4823. St. Gregory 12 R II; DeWindt, 1976:314). The new tenants assumed the burden of support. They agreed to provide shelter, bed and board to an unrelated older generation.

Pensioners consented to the arrangements apparently for the same reasons that they had linked maintenance to a particular holding or tenement. Property was an asset. It generated income and constituted the primary source of support, while either kin or neighbors could provide the means of channeling that income, of administering the requisite aid or assistance. This is not to imply a lack of concern for familial ties, nor is it to say that personal indifference characterized the outlook of the old. Rather, their pension plans remained subject to practical limitations. Inheritance customs, economic and demographic variables, attitudes toward work, health, life-expectancy, privacy, companionship, and the future, all played a part in determining what kind of support men and women wanted or could expect. In general, their expectations coverged along four lines:

(1) Pensioners, in the first instance, preferred not to relocate. Any changes made in housing arrangements reflected the adjustments the old had to make in living with the young. Coresidence usually was the norm in households headed by smallholders. These men and women, like the hapless elderly of folkstories, found themselves relegated to a "garret" in an attic, or merely left with a "small space for a bed" and a "place by the fire." Only the well-to-do expected privacy. When their houses included several rooms, pensioners claimed specific ones as their own and forbade use to anyone else. They ensured their own freedom of movement by demanding access to kitchens (conquine), to pantries, to "latrines," to wells for drawing water, to barns for stocking wood or underbrush. Sometimes they remodelled a house to include a "parlour," a "bedchaumbre," or a room called the "spense." When the old wanted a dwelling entirely of their own, they reserved for themselves the use of a detached house variously styled the "besthous," the "newhous," the "oldhous." The preference for separate quarters accounted for one contract in every twelve and generally depended on the nature of a pensioner's accumulated resources, on the physical layout of his tenement, and the design of its facilities for preparing food.

TABLE 1. SIZE OF HOLDINGS RECORDED IN PENSION CONTRACTS IN EAST ANGLIA, 1258-1457.

\begin{tabular}{|c|c|c|c|}
\hline & \multirow[t]{2}{*}{ Size } & \multicolumn{2}{|c|}{$\begin{array}{l}\text { Percent of } \\
\text { Total Number }\end{array}$} \\
\hline & & Pre -1350 & Post-1350 \\
\hline \multirow[t]{6}{*}{ Less than: } & 5 acres & 55.2 & 54.4 \\
\hline & 10 acres & 79.3 & 71.9 \\
\hline & 15 acres & 86.2 & 80.7 \\
\hline & 20 acres & 96.5 & 93.0 \\
\hline & 40 acres & 100.0 & 100.0 \\
\hline & $N$ & 29 & 114 \\
\hline
\end{tabular}

(2) Throughout East Anglia and especially in Norfolk, where customary tenements were often partible, aging tenants expected to retire on the basis of relatively modest holdings. Table 1 shows that only 
one-fourth of pensioners surrendered ten acres or more to their benefactors. Fully one-half of the cases entail less than five acres. ${ }^{9}$ For new tenants the problem of subsistence may have been alleviated by the availability of additional arable for lease either from a neighbor's field or the lord's demesne. Income from by-employments, from industry and trade, and from casual day labor, provided another remedy, especially in East Anglian villages within radius of Norwich, Yarmouth, and London. As for pensioners themselves, there is little evidence to suggest that they already had any considerable rents from sublets. Nor is there much evidence to indicate that aging tenants sold off portions of their land as their children grew up and left home. Yet the evidence at hand is sufficiently complex to show that the old carefully planned the maximum use of available resources.

(3) Pension contracts, by their very detail, often limited the discretionary control of new tenants over the disposition of the resources they had acquired from the old. Many pensioners stipulated how their land was to be cropped, what portion of the yield they expected, whether measured by the bushel or by the acre, whether comprised solely of wheat or barley, a combination of both, or a mixture that also included oats, rye and beans. Some pensioners chose late September for delivery of their grain; others wanted payment prorated throughout the entire year. Pensioners also planted gardens, kept bees for honey, and tended little orchards for apples and pears. When the farmstead included animals, pensioners ordered them kept at the new tenant's expense and, in this way, ensured a supply of milk, eggs, meat, and wool. On tenements with ponds, old men claimed

\footnotetext{
${ }^{9}$ These holdings, however, may have represented important levels of agricultural productivity (Campbell, 1982b).
}

the right to go fishing whenever they wished. All assigned the upkeep of buildings, along with the repair of fences and boundaries, to new tenants.

(4) A small number of pensioners expected the arrangements to remain in force for four to nine years. ${ }^{10}$ Yet few pensioners, it seems, were obsessed with their own immediate death, although many worried about a new tenant's premature demise. At issue, then, was a need to limit the extent of dependency and to win the assurance that, come what might, a pensioner could count on receiving the benefits promised him. Contracts provided that assurance; they gave aging tenants the right of appeal either to a manor's administrative hierarchy or to the courts. Both had the power to coerce performance. Both made it likely that obligations to the old would be honored whether incurred by family or nonkin. Their mutual standing at law is of added interest for the following reason.

In East Anglian courts, before 1350, about one-half of the pensioners negotiated contracts with their own children; after 1350 , less than one-quarter of the agreements involved parents and children. ${ }^{11}$ This may have been due to the premature death of heirs or to the very considerable mobility of the rural population in postplague years. Of equal import, both before and after the Black Death,

${ }^{10}$ The terms are mentioned in 32 contracts whereby pensioners sold their holdings but allowed the buyer to pay off the purchase price in yearly installments. See Appendix for examples. The practice suggests how tenants of the elderly gained access to a source of credit; also how deferred payments gave pensioners a cash annuity.

"Of the 45 pre- 1350 contracts, 20 mention the pensioner's children: sons (15 cases); daughters ( 5 cases); 1 granddaughter. Of the 114 cases after 1350 . we see 21 sons, 4 daughters, 1 grandson; 2 contracts among brothers, 1 involving a brother and sister; 3 involving pensioners and benefactors with the same surname. 
TABLE 2. PARTIES TO PENSION CONTRACTS IN EAST ANGLIA, 1258-1457.

\begin{tabular}{|c|c|c|c|c|}
\hline & \multicolumn{2}{|c|}{$\begin{array}{l}\text { Percent Receiving } \\
\text { Pensions }\end{array}$} & \multicolumn{2}{|c|}{$\begin{array}{c}\text { Percent Providing } \\
\text { Pensions } \\
\end{array}$} \\
\hline & Pre-1350 & Post-1350 & Pre- 1350 & Post-1350 \\
\hline Married Couples & 15.5 & 38.7 & 28.8 & 45.9 \\
\hline Men Alone & 42.2 & 23.3 & 64.4 & 50.0 \\
\hline Women Alone & 42.2 & 37.9 & 6.6 & 4.0 \\
\hline $\mathrm{N}$ & 45 & 114 & 45 & 114 \\
\hline
\end{tabular}

may have been "customary expectations" that obviated the need for contracts between all parents and children. Yet, no matter how we account for the post-plague figure, it is in keeping with other data on landholding in English villages; the data specifically show that during the latter half of the fourteenth century, one-third to almost one-half of the number of holdings were transferred to tenants other than children after the death of the head of the household. ${ }^{12}$ The pattern reinforces the impression that childless pensioners may not have been unusual. Although a few did look to brothers and sisters for support, our records stipulate no explicit filial tie between the pensioner and his benefactor in three-quarters of all postplague cases.

These contracts between the elderly and partners other than children make it desirable to reconsider the view that sees economic security only in terms of the conjugal unit. What the East Anglian evidence suggests is that filial support, while never unimportant, was not the sole means of assistance for pensioners. Maintenance-strategy, particularly in postplague years, involved an element of choice for some men and women whenever they looked for tenants to manage their holdings. Table 2 shows that in East Anglian courts after 1350 , the obligation

\footnotetext{
${ }^{12}$ For an example from Norfolk, see Campbell (1982a); he notes that between 1351 and 1375, one-third of the peasant obituaries recorded in one manor's court-rolls show tenants dying without sons or daughters; for 1376 to 1400 , two-fifths. For further discussion, see Razi (1980:114-131).
}

for a pensioner's welfare was assumed by a male tenant in one-half of all cases; in the remaining half, with minor exceptions, the obligation was incurred by a married couple. Perhaps the domestic structure of English villages was sufficiently flexible to allow some landless peasants a way to find their place by residing with the old, by taking over their holdings in return for the promise of maintenance. In this manner the needs of pensioners could have been met by the land-poor as well as by "parentless children." The practice, whenever operative, would suggest the remarkable adaptability of village households headed by aging tenants in need of pensions.

All maintenance agreements emphasize this matter of personal adaptation to changes brought by old age. Pensioners deliberately effected a redistribution of labor and resources at the local level and, in this way, linked their own final years to benefactors related to them by ties of kinship or simply by contract alone. The arrangement was satisfactory for some, but difficult in the extreme for the very poor. Yet all cast their quest for security within the framework of a set of compromises that balanced the immediate needs of the old against the long-term interests of the young. Together they implemented a private system of support defined by shared resources and characterized not merely by a compact between fathers and sons but, just as importantly, by a negotiated agreement between the retired and the employable. 


\section{APPENDIX: MAINTENANCE AGREEMENTS}

The maintenance contracts discussed in this essay have been collected as a byproduct of research on local litigation in medieval English villages and towns. Although the contracts are all those that survive among the archival material listed below, the contracts themselves can only suggest general trends. The reasons for this are several. The first stems from the vagaries of record-keeping over time. Manor courts usually met once every three to four weeks, and thus had twelve to eighteen sessions in a given year. Notwithstanding this fact, the records for every year's courts do not always survive in a continuous series. This is not to say that court rolls are never complete, but rather that most of the records examined here commonly cover three to five sessions per year. Consequently these records, even when grouped together regionally, do not lend themselves to a statistical analysis of the frequency of pension plans. In the second place, no manorial documents list the actual number of all the elderly in a local population. From this it follows that our ability to reconstruct the life-cycles of individuals is seriously affected by the lack of age-specific detail in court rolls that are not continuous. Finally, it must be kept in mind that maintenance contracts represent only a portion, indeed a very small one, of total court proceedings. Still, the detail, the range, and the complexity of the available evidence do bring to the foreground the issue of pension rights in a historical setting; and for this reason, the usefulness of court records should not be underestimated.

The East Anglian records have been searched at the Essex Record office in Chelmsford, the Suffolk Record Offices in Bury St. Edmunds and Ipswich, the Norfolk Record Office at Norwich. I have also used the Berkshire Record Office at
Reading, the Greater London Record Office, and the Public Record Office in London. All the Holkham Hall material for western Norfolk has been read on microfilm at the University of Michigan, Harlan Hatcher Graduate Library.

Court rolls are as follows:

Essex Record Office (ERO): Ingatestone, Harlow Bury, Wethersfield, Moulsham.

Greater London Record Office (GLRO): Harrow.

Norfolk Record Office (NRO): Hindolveston, Horsham St. Faith, Heacham, Sherbourne, Gressenhale, Wymondham, Sedgeford, Banyngham, Eaton, Hevingham, Blickling, Felbrigg, East Beckham Isaacs, Aylmerton, Worstead, Hunstanton, Northwold.

Public Record Office (PRO): Rickling, Dunmow, Fakenham, Brightwalton, Cookham.

Suffolk Record Office (SRO): Walsham-le-Willows, Norton Hall, Little Haugh, South Elmham, Horham, Flixton, Westwood.

Holkham Papers: Wells, Tittleshall, Billingford.

The range of material included in maintenance contracts is suggested by the cases below; they have been edited to show only the specific details of maintenance. For references to Latin editions, see Homans (1941:144-150); see also Raftis (1964:42-46). For royal courts, see Brand (1978). For borough courts, see Martin (1973:78). For corrodies, see Harvey $(1977: 120,167,193)$, and also Hilton (1966:52, 111-113).

Gressenhale. NRO ING 27. Nativity of St. John the Baptist 34 E I. From Henry the son of Leste to Henry the son of Emma atte Stiele 1 messuage, 17 acres. Conditions: "honest and competent" care for life; if discord arises so that they cannot live together, the new tenant must provide yearly 8 bushels of wheat, 8 bushels of rye, 
32 bushels of barley; if the old tenant predeceases the new tenant, then the latter must pay 20s. to cover burial and funeral expenses. Entry fine 28s.

Gressenhald. NRO ING 74. St. Hillary 29 E III (?). From Henry the son of Stephen to Henry the son of Richard and Emma, his wife, and their heirs a third part of 1 messuage, 5 acres with meadow. Conditions: they pay him 20s. at the next feastday of St. Martin; yearly 40 bushels of grain, to wit, at 20 September 24 b. barley, at Christmas $8 \mathrm{~b}$. wheat, at Easter $8 \mathrm{~b}$. rye; yearly 2 pairs of sheets, $3 \mathrm{~s}$. to have his clothing washed, 1 pair shoes, 2 pairs stockings, fodder. Entry fine 10s.

South Elmham. SRO HA $12 / \mathrm{C} 2 / 22$. St. Luke $9 \mathrm{H} \mathrm{IV}$. At the court held here on Monday after the feast of St. Peter-inChains $5 \mathrm{H} \mathrm{IV}$, the jury presented that Henry Pekke died seised of 1 messuage, 10 acres, $1 / 2$ rod of customary land. His grandson, Henry Pekke, is his heir and is of legal age. He requests admittance to the tenement. But Joan Recher, the late Henry's widow, requests half of the tenement as dower. She is admitted. Henry is admitted to the other half with reversion of dower etc. to hold to himself and his heirs for services etc. Henry surrenders his half to the use of Joan for life. She resurrenders the entire tenement to him and to his heirs, but reserves 1 lower room (camera) and 1 upper room (solar), also a parcel of land, with free entry and exit for herself and her friends for life. Conditions: she is to receive yearly at 30 November 1 quarter of faggots valued at 12d.; yearly for life, $8 \mathrm{~s}$. paid in quarterly installments at 30 November, Easter, 24 June, 29 September; Henry to keep her 2 rooms fully repaired; he is to provide her with the same food and drink that he himself has, and if she is not pleased with this fare, she is to have $12 \mathrm{~d}$. yearly on account of her displeasure; entry to the main house whenever she wishes.

Wymondham. NRO 18484. St. Hilary 14 H IV. From William Hardyng and Agnes, his wife, to Richard Hardyng and Margaret, his wife, 2 acres, 3 rods of customary land and half a messuage from the tenement "hyggs and plokett"; 3 rods, 10 perches from the tenement "retherys" with appurtenances in Norton. Conditions: food and drink, clothing, footwear and all other necessities; the new tenants to discharge all the old tenants' debts; the new tenants to cover all funeral expenses and to arrange for Masses to be celebrated in the church of Wymondham for the souls of William, Agnes and their benefactors. Entry fine 10s.

Harlow Bury. ERO D/DEs M3. St. Margaret $3 \mathrm{H} \mathrm{V}$. From William Chaloun and Olivia, his wife, to his former servant, John Pyper, a weaver, 1 messuage with a garden adjacent to the marketplace Conditions: 100s. paid off in 10 installments at Christmas and 24 June for 5 years; 1 room within the tenement; access to 2 pairs of shears; maintenance of 1 pig, 2 hens; profits of and easement to the garden. Entry fine $6 \mathrm{~s} .8 \mathrm{~d}$.

Wymondham. NRO 10103a. St. Peter-inChains $7 \mathrm{H} \mathrm{V}$. From William Notte to John, his son, and Joan, his wife, and their heirs and assigns 1 messuage, 10 acres of the tenement "Banymouth," $41 / 2$ acres of the tenement "Rewald," 1 rod of the tenement "Hardened," $1 / 2$ acre at Shirwod, $1 / 2$ acre called "Qwythed," and 1 property with appurtenances in Watt. Conditions: reservation of 1 room with solar at northern end of hall; food and clothing; William to warm himself at their fire and to have a horse, a saddle and a bridle in order to ride whenever he wishes; annually they will plow and seed 4 acres of 
his in a field called "Kalleye"; they will maintain 24 ewes. Entry fine 3 li.

Wymondham: Cromwell. NRO 18502. St. Petromilla 5 H VI. From Richard Sothereye, when dying, to Nicholas Blithe and Alice, his wife, 2 acres, $1 / 2$ rod of customary land of the tenement "Eliot," and 1 built-up property with appurtenances in Sutton. Conditions: they pay to his wife, Alice, 6 li. in yearly installments of $13 \mathrm{~s} .4 \mathrm{~d}$. at 29 September; reservation to his widow of 1 room at south end of the hall; she may warm herself by their fire as often as she wishes; they will build for her a "chymne" of clay; if the new tenants predecease the widow, or if the husband dies and his wife remarries, still a room must be reserved to the widow. Entry fine $6 \mathrm{~s} .8 \mathrm{~d}$.

Horsham St. Faith. NRO 19509. Conversion of St. Paul $17 \mathrm{H}$ VI. From Margaret, widow of Clement Chapelyn, to John Chapelyn and his heirs 1 acre, 1 rod of "werkland" and 3 acres called "molond." Conditions: widow to have for life 1 hall called "la newhalle," a storeroom at the east end of the hall; access to a kitchen under the roof of the new hall; easement in the bake-house for malting 32 bushels of barley with John's kiln (torallum); half of 1 "golfstede" in the west part of the grange; a stable at the west end of the messuage except during the fair of St. Faith when its use is reserved to John; easement to a well for drawing water; free ingress and egress in the garden for "visiting" bees; 1 cow, 1 pig, 1 cock, 6 hens kept in the said messuage; if John predeceases the widow, then his heirs or assigns to pay her yearly for life $6 \mathrm{~s}$. 8d. at Michaelmas; John to have free entry and exit in the widow's upper room in order to enter his own upper room; John to have easement in the kitchen. Entry fine 26s. 8 d.
Gressenhale. ING. 10 August $33 \mathrm{H}$ VI. From John Bowell and Emma his wife to John Estwyth and Cecilia his wife 1 messuage, 1 cottage, 10 acres, $1 / 2$ rod customary land in diverse tenements. Conditions: 1 lower room at north end of main house; 1 lower room at east end; north end of grange for storing grain; 1 cow along with pasture in summer; $4 \mathrm{~d}$. yearly; 1 pig, 1 cock, 8 hens; half of all the fruit within the messuage; half of the hemplond; $2 \frac{1}{2}$ acres of land to cover expenses for life; new tenants to pay 6 marks 3s. 4d. in yearly installments of $3 \mathrm{~s} .4 \mathrm{~d}$, at Christmas, and 3s. 4d. at Easter.

\section{BIBLIOGRAPHY}

Brand, P. A.

1978 "Oldcotes y. d'Arcy," In R. F. Hunnisett and J. B. Post, eds., Medieval Legal Records Edited in Memory of C. A. F. Meekings. London: Her Majesty's Stationery Office.

Campbell, Bruce M. S.

1980 "Population Change and the Genesis of Commonfields on a Norfolk Manor."Economic History Review, 2nd ser. 33.

1982a "Population Pressure, Inheritance and the Land Market in a Fourteenth Century Peasant Community. In R. M. Smith, ed., Land, Kinship and Life-Cycle (forthcoming).

1982b "Agricultural Progress in Medieval England: Some Evidence from Eastern Norfolk." Economic History Review (forthcoming).

Clark, Elaine

1982 "Debt Litigation in a Late Medieval Essex Vill." In I. A. Raftis, ed., Pathways to the Medieval Peasant. Toronto: Pontifical Institute of Mediaeval Studies.

DeWindt, E. B.

1976 The Liber Gersumarum of Ramsey Abbey: A Calendar and Index of B. L. Harley MS 445. Toronto: Pontifical Institute of Mediaeval Studies.

Goody, Jack, Joan Thirsk and E. P. Thompson

1976 Family and Inheritance: Rural Society in Western Europe, 1200-1800. Cambridge: Cambridge University Press. 


\section{Harvey, Barbara}

1977 Westminster Abbey and Its Estates in the Middle Ages. Oxford: Clarendon Press.

Hatcher, John

1977 Plague, Population and the English Economy, 1348-1530. London: Macmillan.

Hilton, R. H.

1966 A Medieval Society: The West Midlands at the End of the Thirteenth Century. New York: Wiley.

1975 The English Peasantry in the Later Middle Ages. Oxford: Clarendon Press.

Homans, G. C.

1941 English Villagers of the Thirteenth Century. Cambridge, Mass.: Harvard University Press.

MacFarlane, Alan

1979 The Origins of English Individualism. New York: Cambridge Lniversity Press.

Martin, G. M.

1973 The Ipswich Recognizance Rolls, 12941327. Suffolk Records Society 16.

Page, F. M.

1930 "The Customary Poor Law of Three Cambridgeshire Manors." Cambridge Historical Journal 3.

Postan, M. M.

1972 The Medieval Economy and Society. London: Weidenfeld and Nicolson.

1973 Essays on Medieval Agriculture and General Problems of the Medieval Economy. Cambridge: Cambridge University Press.
Pound, John

1971 Poverty and Vagrancy in Tudor England. London: Longman.

Raftis, J. A.

1964 Tenure and Mobility: Studies in the Social History of the Mediaeval English Village. Toronto: Pontifical Institute of Mediaeval Studies.

Razi, Zvi

1980 Life, Marriage and Death in a Medieval Parish: Economy, Society and Demography in Halesowen, 1270-1400. Cambridge: Cambridge University Press.

1981 "Family, Land and the Village Community in Later Medieval England." Past and Present 93.

Searle, Eleanor

1979 "Seigneurial Control of Women's Marriage: The Antecedents and Function of Merchet in England." Past and Present 82.

Smith, Richard M.

1979. "Kin and Neighbors in a Thirteenth Century Suffolk Community," Journal of Family History 4.

Titow, J, Z,

1969 English Rural Society, 1200-1350. London:

Webb, John Allen and Unwin.

1966 Poor Relief in Elizabethan Ipswich. Suffolk Records Society 9. 